\title{
Clinton's technology policy under dual siege in Congress
}

Washington. President Bill Clinton's plan to boost US industrial research and development was caught in congressional crossfire last week, and may have been seriously damaged in the process. The president hopes to quadruple the budget of the National Institute of Standards and Technology (NIST) to \$1.4 billion a year by 1997 .

Last week, \$220 million of 1994 funding for NIST, including all of its planned construction projects as well as the research money it grants to industrial companies under its Advanced Technology Program (ATP), was knocked out of the Commerce, State and Justice appropriations bill on a technicality.

Although supporters of NIST are confident that most of the money will be restored, the setback highlights the difficulties the administration is encountering in attempting to find large amounts of new money to pay for its technology policy.

NIST, which employs 3,200 people on two major sites at Gaithersburg, Maryland, and Boulder, Colorado, has expertise in physics and engineering. The new administration identified it in February as a promising basis for a major and, in the United States, unprecedented government programme to bolster industrial research, especially in small companies.

But the NIST money was a sitting target for its critics last Thursday because the bill to authorize it had not yet been passed. Any congressman could therefore strike it out by raising a point of order.

Robert Walker (Republican, Pennsylvania), the senior Republican on the House of Representatives Science, Space and Technology Committee and an ideological opponent of the use of state funds for schemes such as the ATP, duly stood up to quash the appropriation. The commerce appropriations subcommittee had proposed spending \$129 million on the ATP and $\$ 30$ million on the Manufacturing Extension Partnership, another industry support scheme.

Then Lincoln Diaz-Balart (Republican, Florida), whose interest in science policy has hitherto been inconspicuous, knocked out NIST's \$61-million building programme. Diaz-Balart had noticed that the money would be spent renovating NIST's laboratory at Boulder, Colorado, in the district of David Skaggs (Democrat, Colorado). But Skaggs had earlier supported the closure of Television Marti, a station broadcasting to a very small audience in Cuba, and whose broadcasts are always jammed.
Diaz-Balart wanted revenge on Skaggs, and so struck out the NIST money. Procedural skirmishes of this kind, common on school playgrounds, are not unprecedented in the Congress.

Supporters of the administration's technology policy hope to restore NIST's funding when the House and Senate seek to reach a compromise in the autumn. But this may be more difficult than they expect, given

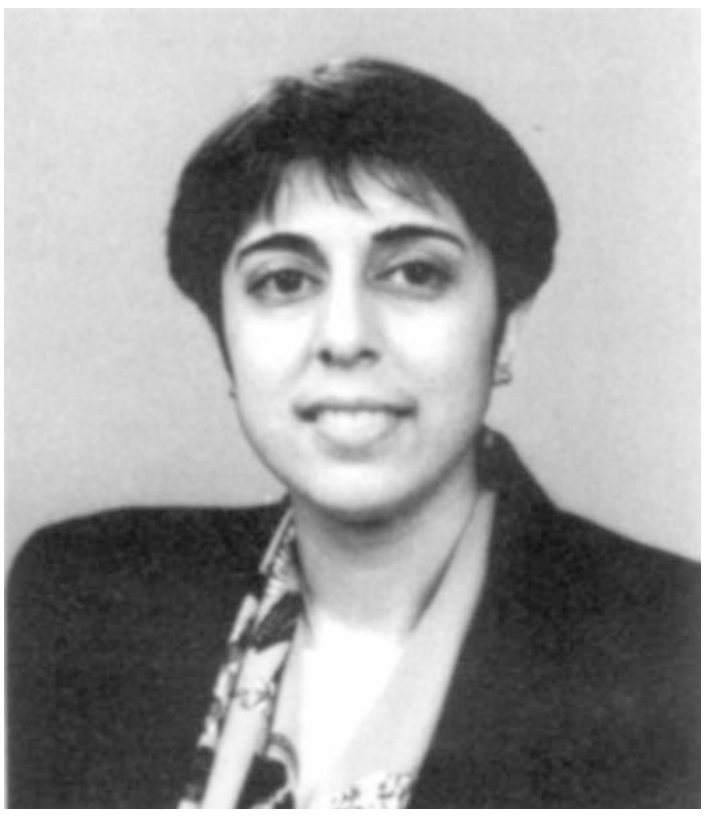

NIST's director Arati Prabhakar: will she see her budget increase?

competing demands for available funds. After the NIST money was struck out, the House voted to spend an extra $\$ 60$ million from the same pot on 600 extra guards for the Mexican border - a more pressing concern, to many congressmen, than developing long-term mechanisms for technology transfer.

The ATP, which NIST started three years ago, makes grants of the order of $\$ 1$ million to help companies or groups of companies on specific research projects. Clinton wanted an extra $\$ 103$ million for ATP this year as part of his economic stimulus package, which fell in Congress in the spring. Next year's budget request for $\$ 200$ million had been cut back to $\$ 129$ million by the appropriations subcommittee even before last Thursday. All that makes the administration's stated objective of spending $\$ 750$ million a year on ATP by 1997 look somewhat ambitious.

Arati Prabhakar - appointed NIST director in May - remains confident about her agency's future role at the heart of the administration's technology policy. "I'm still optimistic we are going to make some progress", she says. "The appropriations subcommittee approved its biggest ever increase for NIST, and the floor action is really a technicality." Prabhakar also contends that resistance to technology programmes has historically come from the administration, not from Congress.

The objective of ATP's expansion is that it should grow so as to make a substantial impact on US competitiveness, but Prabhakar declines to say just how big it would have to be for that to happen. The administration reckons that, if the United States spends $\$ 150$ billion a year on research and development, a federal stimulus of half a per cent - $\$ 750$ million - is needed, but "there is nothing magic about that number", Prabhakar says.

US industry is pleased to get what it can from the ATP's coffers, but is not yet convinced that the scheme has justified the faith the administration places in it. "We support the ATP as an experiment, and it was a mistake of the Bush administration to starve it of funds", says Bill Morin of the National Association of Manufacturers. But the industry lobby group does not expect ATP or other NIST programmes to grow as spectacularly as Clinton wants. Morin believes that the idea that NIST would grow that rapidly was "probably unrealistic". "Gridlock is alive and well, and living in Congress."

But if Clinton's technology policy plan is stymied by Congress so that its impact on the \$150-billion research effort will be undetectable, what it is the point of doing it at all? That is just the kind of question that earlier this year killed two of Clinton's main policy objectives - the stimulus package and the energy tax. In both cases, ambitious schemes were whittled down to appease opponents, and then defeated because they looked inadequate to meet their respective objectives.

Henry Kelly, a technology adviser at the Office of Science and Technology Policy in the White House, acknowledges that there is an uphill struggle ahead. "One of our problems is getting people to understand the role a technology policy can play in the economy," he says. "We are committed to making NIST a major player. Obviously it would be much easier to achieve what we want to if the budget was expanding. Given the reality of the budget situation, it is going to be difficult."

Colin Macilwain 